Acute stem cell transplantation: perceptions and coping predict distress

This a pre-publication, uncorrected proof and is provided for information only. The citation for the published journal paper is:

Baliousis, M., Rennoldson, M., Dawson, D. L., Mills, J., \& das Nair, R. (2017, January). Perceptions of Hematopoietic Stem Cell Transplantation and Coping Predict Emotional Distress During the Acute Phase After Transplantation. In Oncology Nursing Forum (Vol. 44, No. 1, p. 96).

\title{
Perceptions of haematopoietic stem cell transplantation
}

\section{and coping predict emotional distress during the acute}

\author{
phase
}

Dr Michael Baliousis, Trainee Clinical Psychologist, University of Nottingham

Dr Michael Rennoldson, Senior Lecturer, Nottingham Trent University, Nottingham, UK

Dr David L Dawson, Research Clinical Psychologist, University of Lincoln, Lincoln, UK

Dr Jayne Mills, Clinical Psychologist, Nottingham University Hospitals NHS Trust, Nottingham, UK

Prof Roshan das Nair, Consultant Clinical Psychologist, University of Nottingham, Nottingham, UK \& Nottingham University Hospitals NHS Trust, Nottingham, UK

Correspondence:

Prof Roshan das Nair, Division of Psychiatry and Applied Psychology, YANG Fujia Building, University of Nottingham, Jubilee Campus, Wollaton Road, Nottingham, NG8 1BB, UK

Email: roshan.nair@nottingham.ac.uk

Tel: $01158230371 / 8468314$ 
Acute stem cell transplantation: perceptions and coping predict distress

\begin{abstract}
Purpose/objectives: To test whether a widely used model of adjustment to illness, the self-regulatory model, explains the patterns of distress during acute haematopoietic stem cell transplantation (HSCT). According to the model, perceptions of HSCT, coping, and coping appraisals are associated with distress.
\end{abstract}

Design: Longitudinal, correlational.

Setting: Two centres of clinical haematology, UK.

Sample: 45 patients receiving mostly autologous transplants for haematological malignancies.

Methods: Patients were assessed at baseline, on transplant day, and two and four weeks after transplantation using three questionnaires: The Short Depression Anxiety Stress Scales (DASS-21), Brief Coping with Problems Experienced (Brief COPE), and Brief Illness Perceptions Questionnaire adapted for HSCT (Brief IPQ). Multilevel regression was used to analyse the clustered dataset.

Main Research Variables: Psychological distress including depression, anxiety, stress, and overall distress (DASS-21), use of different coping styles (Brief COPE), and perceptions of HSCT and coping appraisals (Brief IPQ).

Findings: As suggested by the self-regulatory model, higher distress was associated throughout the period with negative perceptions of HSCT, controlling for the effects of confounding variables. Mixed support was found for the model's predictions about the impact of coping styles upon distress. Use of active and avoidant coping styles was associated with more distress during acute HSCT.

Conclusions: Negative perceptions of HSCT and coping contribute to psychological distress during acute HSCT and suggest the basis for intervention. 
Acute stem cell transplantation: perceptions and coping predict distress

Implications for nursing: Eliciting and discussing patients' negative perceptions of HSCT beforehand and supporting helpful coping may be important ways of reducing distress during HSCT.

\section{Knowledge translation:}

- Patients are more distressed when they perceive HSCT negatively, and risk becoming stuck in a vicious cycle, because distress appears worse if patients attribute it to undergoing HSCT.

- Avoidant coping is associated with worse distress, but positive approach coping that is helpful in other populations seem to be ineffective during HSCT.

- Discussing patients' negative perceptions of HSCT and identifying effective coping approaches for patients undergoing HSCT is important.

Key words: cancer, oncology, stem cell, bone marrow, perceptions, coping 
Acute stem cell transplantation: perceptions and coping predict distress

\section{Introduction}

Haematopoietic stem cell transplantation (HSCT) is a complex and intensive procedure whose acute phase can last several weeks, involving high toxicity, prolonged isolation, and a range of debilitating side effects (e.g., fatigue and nausea) (Anderson et al., 2007; Copelan, 2006; Prieto, Atala, Blanch, Carreras, Rovira, Cirera, \& Gastó, 2005). Patients report an overwhelming experience and loss of agency, describing the procedure as a "walk to hell and back" and "really, really hard" (Xuereb \& Dunlop, 2003, p. 404). Surveys of psychiatric morbidity in HSCT patients have found that approximately half of patients meet clinical criteria for anxiety or depression during the first weeks, with anxiety often highest around admission, and depression increasing thereafter (Fife et al., 2000; Lee et al., 2005;

Prieto, Atala, Blanch, Carreras, Rovira, Cirera, \& Gastó, 2005; Tecchio et al., 2013). The impact of such distress on recovery from HSCT has been documented, and may include: reduced pain and symptom tolerance, longer hospital stay, and poorer treatment adherence, immune recovery, and survival rates (Hoodin, Uberti, Lynch, Steele, \& Ratanatharathorn, 2006; Park et al., 2010; Prieto, Atala, Blanch, Carreras, Rovira, Cirera, Espinal, et al., 2005; Prieto et al., 2002; Pulgar, Garrido, Alcalá, \& Reyes del Paso, 2012; Schulz-Kindermann, Hennings, Ramm, Zander, \& Hasenbring, 2002).

Clinical and demographic predictors of distress during HSCT have been extensively investigated (e.g., Fife et al., 2000; Hefner et al., 2014; Prieto, Atala, Blanch, Carreras, Rovira, Cirera, \& Gastó, 2005; Schulz-Kindermann et al., 2002; Tecchio et al., 2013). However, the literature on psychological predictors of distress is less well developed. From this work, disparate factors such as personal control and meaning-making (Fife et al., 2000), sense of coherence (Pillay et al., 2015), 
Acute stem cell transplantation: perceptions and coping predict distress

acceptance of distress (Bauer-Wu et al., 2008), and diversion of attention from pain (Schulz-Kindermann et al., 2002) appear to be important. However, we argue that the absence of a unifying and well-developed psychological theory from this research has hampered the development of timely and effective psychological interventions for HSCT patients. This may partly explain the sparse and limited effectiveness of such interventions in HSCT and lack of clarity regarding what contributes to outcome (Baliousis, Rennoldson, \& Snowden, 2016; Braamse et al., 2016).

The most widely applied model of psychological adjustment to illness is the self-regulatory model (Hagger \& Orbell, 2003; Leventhal et al., 1997; Ogden, 2012; Sharpe \& Curran, 2006). It conceptualises the process of psychological adjustment to illness as comprising three interacting components: interpretation, coping, and appraisal of coping (Figure 1). A person's interpretation, or illness perception, includes their view of the severity of the consequences of the illness, duration, identity (its label and symptoms for the person), concern, level of understanding, and emotional impact. Coping describes the process of implementing strategies to reduce the psychological threat perceived by the person, and any resultant negative emotions. Two broad types of coping often associated with outcomes and distress have been used with the self-regulatory model: approach and avoidance coping (Ogden, 2012; Taylor \& Stanton, 2007). Approach coping involves confronting the stressor (e.g. problem-solving, planning, use of support, etc.) while avoidance reflects disengaging from it (e.g., denial, distraction) (Taylor \& Stanton, 2007). Appraisal of coping forms a feedback loop, evaluating the effectiveness of the person's coping efforts (Hagger \& Orbell, 2003). 
Acute stem cell transplantation: perceptions and coping predict distress

All three elements of the model have been extensively investigated and largely validated in other health populations. For example, more negative illness perceptions have been found to predict negative health-related outcomes including emotional distress and poor physical functioning (Arran, Craufurd, \& Simpson, 2013; Hagger \& Orbell, 2003; Hall, Weinman, \& Marteau, 2004; Knibb \& Horton, 2008; Parry, Corbett, James, Barton, \& Welfare, 2003; Petrie, Cameron, Ellis, Buick, \& Weinman, 2002; Rizou, De Gucht, Papavasiliou, \& Maes, 2015; Vaughan, Morrison, \& Miller, 2003). Avoidant coping may be unhelpful, whilst engaging with the challenges of the illness and accessing social resources to support coping may be more helpful (Folkman \& Moskowitz, 2004; Grant et al., 2013; Knibb \& Horton, 2008; Sikkema et al., 2013; Taylor \& Stanton, 2007). Positive appraisals of coping have also been found to predict higher levels of emotional well-being (Hagger \& Orbell, 2003; Knibb \& Horton, 2008; Rizou et al., 2015). Crucially, all three elements of the model have also been associated with physical recovery, predicting complications, treatment adherence, return to work, and general physical functioning and quality of life (Cherrington, Moser, Lennie, \& Kennedy, 2004; Hagger \& Orbell, 2003; Helder et al., 2002; Knowles et al., in press; Petrie et al., 2002; Zoeckler, Kenn, Kuehl, Stenzel, \& Rief, 2014). Should such findings be replicated in an HSCT population, the model, which has supported the development of effective interventions in other health populations (Petrie, Broadbent, \& Meechan, 2003; Petrie et al., 2002) may be a promising guide to effective interventions in HSCT. Ultimately, such input could play an important role in alleviating some of the debilitating complications during the procedure.

Of the self-regulatory model's components, only coping has been studied in HSCT populations. However, these studies have focussed on the recovery period 
Acute stem cell transplantation: perceptions and coping predict distress

several months after HSCT (Schoulte, Lohnberg, Tallman, \& Altmaier, 2011; Wells, Booth-Jones, \& Jacobsen, 2009; Wu et al., 2012), therefore, the impact of coping during the acute phase remains unclear since coping styles can have different effects at different times and circumstances (Taylor \& Stanton, 2007). The selfregulatory model refers to illness but HSCT is a medical procedure where it is treatment-related toxicity that poses the greatest challenge in the acute phase. Consequently, the extent to which the model might apply to HSCT requires corroboration. Therefore, the present study examined the applicability of the selfregulatory model (Hagger \& Orbell, 2003; Leventhal et al., 1997; Sharpe \& Curran, 2006) to acute HSCT. We hypothesised that: (a) more negative perceptions of HSCT will be associated with higher levels of distress; (b) avoidance-based coping styles (e.g., disengaging, denial, self-distraction, etc.) will be associated with higher levels of distress; and (c) approach-based coping styles (e.g., active coping, planning, seeking support) will be associated with lower distress.

\section{Method}

\section{Participants}

Participants were recruited from consecutive referrals between January and September 2015 at two haematology departments in different regions of England. Inclusion criteria were: (a) HSCT for haematological malignancy; (b) 18 years or older; and (c) sufficient command of the English language and ability to participate in the study (including hearing ability for data collection over the telephone). Where appropriate, ambulatory care was offered and accepted by some patients, although in practice an admission took place for all participants during the study. 
Acute stem cell transplantation: perceptions and coping predict distress

\section{Materials}

We used brief, well established self-report measures. We followed standard practice by assessing HSCT perceptions and appraisal of coping of the selfregulatory model via the Brief IIIness Perceptions Questionnaire (Brief IPQ) (Broadbent, Petrie, Main, \& Weinman, 2006) and coping styles via the Brief Coping with Problems Experienced (Brief COPE) questionnaire (Carver, 1997; Hagger \& Orbell, 2003). We measured the dependent variable of distress using the Depression Anxiety Stress Scales (DASS-21). All measures asked about the participants' experience over the preceding week.

We selected the DASS-21 due to its brevity (21 items, to reduce burden on participants), coverage of three constructs that may capture the complex distress patterns in HSCT (anxiety, depression, traumatic stress, etc.) (Fife et al., 2000; Lee et al., 2005; Prieto, Atala, Blanch, Carreras, Rovira, Cirera, \& Gastó, 2005; Prieto et al., 2002), and clinical validity in this respect (Antony, Bieling, Cox, Enns, \& Swinson, 1998; Henry \& Crawford, 2005). DASS-21 measures depression, anxiety, and stress (ongoing tension, worry in the context of persistent demands), and provides a total distress score from these three constructs (Antony et al., 1998; Henry \& Crawford, 2005). Each subscale comprises seven items rated on a 4-point Likert scale with total scores between 0-21 for each (higher scores denote higher distress) (Henry \& Crawford, 2005). Moderate level cut-offs (Depression $\geq 7$, Anxiety $\geq 5$, Stress $\geq 10$ ) are representative of clinical populations (Lovibond \& Lovibond, 1995; Ronk, Korman, Hooke, \& Page, 2013). The instrument has good to excellent internal consistency (Cronbach's $\alpha=0.82-0.94)$, good criterion validity, acceptable discriminant validity, moderate sensitivity to clinical change, and acceptable to good temporal stability $(r=0.71-0.81)$ in clinical samples (Antony et al., 1998; Brown, 
Acute stem cell transplantation: perceptions and coping predict distress

Chorpita, Korotitsch, \& Barlow, 1997; Henry \& Crawford, 2005; Ng et al., 2007; Page, Hooke, \& Morrison, 2007).

The Brief COPE has been widely used and is relatively short yet comprehensive (Carver, 1997; Carver, Scheier, \& Weintraub, 1989; de Ridder, 1997). It measures several theoretically-derived coping styles. Self-distraction, denial, disengagement, venting, and self-blame are generally considered avoidancebased, whilst active coping, support, positive reframing, planning, humour, and acceptance (vs. denial) are considered approach-based; but groupings can vary across contexts (Carver et al., 1989; Folkman \& Moskowitz, 2004; Taylor \& Stanton, 2007) and have not been established in HSCT. Each style comprises two items rated on a 4-point Likert scale with total scores from 0-6 as a continuous variable (higher scores denoting more frequent use) (Carver, 1997). The instrument has good construct, concurrent, and predictive validity in relation to emotional well-being and adjustment in different clinical populations including HSCT (Bautista \& Erwin, 2013; Cooper, Katona, Orrell, \& Livingston, 2008; Folkman \& Moskowitz, 2004; Hooper, Baker, \& McNutt, 2013; Knowles, Cook, \& Tribbick, 2013; Meyer, 2001; Schoulte et al., 2011). Some limitations to reliability have been reported with Cronbach's $\alpha$ between $0.50-0.90$ and test-retest reliability coefficients between 0.42-0.89 (6-8 weeks) (Carver, 1997; Carver et al., 1989). Low reliability is common among coping measures but the Brief COPE has been found to be one of the most psychometrically robust among them (de Ridder, 1997; Folkman \& Moskowitz, 2004). It is also designed to assess individual coping styles rather than a priori coping style groupings (Carver, 1997; Carver et al., 1989) that have not been established in HSCT. 
Acute stem cell transplantation: perceptions and coping predict distress

The Brief IPQ is based on the self-regulatory model and assesses illness and coping appraisals (consequences, timeline, identity, concern, understanding, emotional impact, personal, and treatment control). It contains eight items each measuring a different perception and rated on an 11-point Likert scale with higher scores reflecting higher endorsement (Broadbent et al., 2006). A higher summary score (0-80) reflects more negative perceptions (Knowles et al., 2013; Løchting, Garratt, Storheim, Werner, \& Grotle, 2013). The measure has been validated in several clinical populations (Bean, Cundy, \& Petrie, 2007; Figueiras \& Alves, 2007; Hagger \& Orbell, 2003; Knowles et al., 2013; Løchting et al., 2013). It has acceptable internal consistency for the summary score (Cronbach's $\alpha=0.58-0.82$ ) and stability ( $r=0.42-0.88$ up to six weeks) (Broadbent et al., 2006; Løchting et al., 2013), and good concurrent, predictive, and discriminant validity (Bean et al., 2007; Broadbent et al., 2006; Knowles et al., 2013; Løchting et al., 2013). We adapted it for HSCT as the original measure refers to illness. For example, the question about consequences "How much does your illness affect your life?" was reworded to "How much does the transplant process affect your life?", the question about timeline "How long do you think your illness will continue?" was reworded to "How long do you think the transplant process will continue?", and so forth.

\section{Design and procedure}

We used a longitudinal design with four time points (Figure 2) to examine the relationships between emotional distress and psychological processes over time. A member of the clinical team invited eligible patients to take part following referral to the service. Interested patients provided informed consent after reviewing the study materials and were given the opportunity to ask questions. At time point 1, participants completed baseline questionnaires (DASS-21, Brief COPE, and Brief 
Acute stem cell transplantation: perceptions and coping predict distress

IPQ) on site or returned them via the post. Participants completed the same questionnaires over the telephone at three further time points: on transplant day, and two and four weeks after the transplant. In light of HSCT's physical side effects (mucositis, etc.) (Copelan, 2006), we also asked participants to attribute physiological symptoms of DASS-21 anxiety (items $2,4,7$, and 19 , referring to dry mouth, breathing difficulty, etc.) to clarify whether they reflected HSCT side effects rather than anxiety, and remove them in the case of the former. We recorded participant characteristics and nonconcordant events (intensive care, patient leaving isolation, psychological input) from clinical records at the end of the study. A National Research Ethics Service Committee in the UK approved the study. A patient panel helped develop the study procedure.

\section{Data analysis}

Preliminary analyses examined descriptive statistics, input errors, outliers, assumptions, and missing data (Field, 2013; Snijders \& Bosker, 2012). We used Cronbach's a coefficients to assess internal consistency (Field, 2013) and removed DASS-21 items that could not be differentiated from HSCT's side effects. As the dataset was clustered within patients, there were missing data, and some assumptions were violated, we used Multilevel Modelling (MLM, developed to deal with clustered data) with nonparametric bias-corrected bootstrapping to include all available information and improve accuracy (Rasbash, Steele, Browne, \& Goldstein, 2015; Snijders \& Bosker, 2012). We examined the effect of time (categorical predictor) and participant characteristics (covariates) on distress and the effect of time on HSCT perceptions and coping styles. For the main analyses, we used MLM to examine the change of HSCT perceptions and coping style over time and their relationship with distress across all time points whilst controlling for previously 
Acute stem cell transplantation: perceptions and coping predict distress

significant covariates. We assessed model improvements $\left(\Delta \mathrm{x}^{2}\right)$ and explained variance $\left(R_{1}^{2}\right)$ at each step of model development (Snijders \& Bosker, 2012). We also examined improvements by taking account of variance across participants (random effects) for significant predictors (Snijders \& Bosker, 2012). We used MLwiN software Version 2.34 (Rasbash, Browne, Healy, Cameron, \& Charlton, 2015) for MLM and SPSS software Version 22 (IBM Corp, 2013) for all other analyses. The level of significance was $\alpha=0.05$.

\section{Results}

\section{Preliminary analyses}

Table 1 presents characteristics of the 45 participants recruited. We removed DASS-21 items 2 (dry mouth) and 7 (trembling) as these reduced reliability coefficients, and $56 \%$ of participants indicated that these items reflected side effects of HSCT rather than anxiety. Cronbach's a coefficients determining internal consistency across time were $0.72-0.95$ for total distress, depression, and stress, and $0.46-0.78$ for anxiety (lower at later time points). For HSCT perceptions, total Brief IPQ coefficients were $0.63-0.68$, which is common for this measure (e.g., Bean et al., 2007; Løchting et al., 2013). The two coping appraisal items appeared to reduce coefficients from over 0.70 . The coefficients of acceptance, positive reframing, behavioural disengagement, denial, self-blame, self-distraction, and venting was variable across time points with at least one coefficient below 0.50 (e.g., acceptance coefficients ranged from 0.23 to 0.81 ). The mean across time points was at least 0.50 for all these scales. Other coefficients were up to 0.94 .

Of the 184 possible data points (45 participants completing questionnaires up to four times) 144 were completed by 44 participants and were included in the final 
Acute stem cell transplantation: perceptions and coping predict distress

dataset (Figure 2). The dataset provided sufficient power to detect at least medium effects in the chosen type of analysis, which would have required between 116 data points (29 participants with full datasets) and 172 data points (43 participants with full datasets), using standard power analyses for MLM (Twisk, 2006). Of the data points, completion was delayed for $15 \%$ (more than two days overdue). Regarding missing data, Little's test was significant, $X^{2}(127)=163.99, P=0.015$, and missing data were related to poorer baseline physical functioning (performance status) at time points 2 and $3, \operatorname{ts}(3.6-7) \geq 3.4, P s \leq 0.03$, and higher baseline and time 2 stress at time point 3 , $t(8.9-34) \geq 2.5, P \leq 0.04$. Missing data could, therefore, be considered mostly random for MLM (Snijders \& Bosker, 2012). Of noncondordant events, one participant received psychological input (time point 3), which may have affected distress.

\section{Effects of time and participant characteristics}

We observed a significant main effect of time for all distress scales except stress (Table 2). This was also reflected in the proportion of patients reporting at least moderate distress (Table 2), reaching $42 \%$ at any time during the acute phase (time points 2-4). Compared to baseline, total distress was significantly higher at time point 3, depression was higher at time points 3 and 4 , and anxiety was higher at time point 3. As covariates, younger participants reported less depression, males reported less distress overall, and those with better baseline physical functioning reported less anxiety and stress across time points, $\Delta \mathrm{X}^{2}(\Delta d f=1) \geq 4.58, P s \leq 0.03$. No other covariates reached statistical significance, $\Delta x^{2}(\Delta d t \leq 2) \leq 5.51, P s \geq 0.06$ (see Table 4 in the online supplement for fixed parameter estimates). Estimation terminated (converged) when random effects were added for physical functioning (total distress), ambulatory treatment (depression), and length of admission (total distress) only (models did not improve significantly). 
Acute stem cell transplantation: perceptions and coping predict distress

\section{Psychological processes}

Overall, negative HSCT perceptions were higher at time points 3 and 4 compared to baseline, $\Delta \mathrm{X}^{2}(\Delta d f=3)=31.4, P<0.001$, but the difference did not reach significance for subscales, $\Delta x^{2}(\Delta d f=3) \leq 6.61, P s \geq 0.09$. More negative perceptions of HSCT and the majority of subscales measured were significantly associated with higher distress across the study period (with identity and understanding showing no relationship with stress [Table 3]).

Of the coping styles, use of self-distraction, active coping, emotional and instrumental support, humour, and positive reframing was higher compared to baseline across time points 2 to 4 (time point 2 only for humour and time points 2 and 3 for reframing), $\Delta x^{2}(\Delta d f=3) \geq 8.42, P s \leq 0.04$, but not use of other styles, $\Delta \mathrm{X}^{2}(\Delta d f=3) \leq 7.48, P s \geq 0.06$. As shown in Table 3, more frequent use of avoidancebased (unhelpful) styles was significantly associated with higher distress. However, more frequent use of approach-based or coping styles considered helpful was also associated with higher distress. The effects of HSCT perceptions and coping remained unchanged after controlling for age, gender, and physical functioning.

\section{Discussion}

We examined whether HSCT perceptions and coping predict distress during the acute phase of HSCT in line with the self-regulatory model (Hagger \& Orbell, 2003; Leventhal et al., 1997; Sharpe \& Curran, 2006). The results supported the model given that negative HSCT perceptions and coping styles predicted distress during acute HSCT. This extends the literature during this period of HSCT, which has previously focused predominantly on clinical and demographic variables (Fife et 
Acute stem cell transplantation: perceptions and coping predict distress

al., 2000; Prieto, Atala, Blanch, Carreras, Rovira, Cirera, \& Gastó, 2005; SchulzKindermann et al., 2002; Tecchio et al., 2013).

\section{Perceptions of HSCT and coping}

The results support the hypothesised role of negative interpretations about HSCT in maintaining distress, including how physical symptoms are perceived. This is consistent with qualitative research findings highlighting loss of meaning and interpretations of threat in HSCT, and with the wider literature on cognitions in depression, anxiety, and stress, suggesting the relevance of negative outlook, perceptions of threat, and challenge respectively (Lazarus, 2000; Tarrier, 2006; Xuereb \& Dunlop, 2003). The effect of perceived emotional impact of the procedure was particularly high, indicating that patients experiencing distress generally attributed this to HSCT and, in conjunction with other perceptions of HSCT (e.g., lengthy course), may compound distress. However, the large association between distress scales and this Brief IPQ item also suggests the measures may overlap conceptually.

The lack of association between coping appraisals (personal and treatment control) and distress was contrary to expectations. However, these items did not appear internally consistent within the Brief IPQ. This has also been observed in other studies (Morgan, Villiers-Tuthill, Barker, \& McGee, 2014) and the items have shown variable ability to predict distress (Hagger \& Orbell, 2003), which might suggest a limitation to the contribution of coping appraisals (and the self-regulatory model) in some populations, including HSCT. However, the complexity of HSCT, heterogeneity of care (Copelan, 2006), and social desirability when rating helpfulness of treatment (treatment control) may have introduced complexity in these 
Acute stem cell transplantation: perceptions and coping predict distress

appraisals that was not possible to capture in the current research. The null results may also reflect the findings in relation to coping.

The findings indicated that several coping styles were ineffective. Whilst this was expected for avoidance-based styles, it was not expected for those that are considered helpful in the wider literature such as planning and support-seeking (Carver et al., 1989; Taylor \& Stanton, 2007). Studies examining the post-acute period of HSCT have not observed reliable effects of these latter styles (Schoulte et al., 2011; Wells et al., 2009) but it is possible that the circumstances of acute HSCT may render many coping strategies ineffective or counterproductive. For example, an adverse effect of planning has been noted in acute cancer care but not subsequent periods (Carver et al., 1993). This lack of effectiveness in acute cancer care and HSCT may be due to limited access to resources so that planning becomes inert. Furthermore, social support is believed to provide a resource for coping (Taylor \& Stanton, 2007) but the acute phase of HSCT, which encompasses isolation and disabling side effects (Copelan, 2006), may render attempts to use this resource inert (Schulz-Kindermann et al., 2002). These observations may also explain the lack of reliable associations between distress and perceptions of personal and care control.

\section{Distress patterns}

Results replicated the pattern of high but declining anxiety and increasing depression that has been found in other HSCT studies, including the acute phase (Fife et al., 2000; Lee et al., 2005; Prieto, Atala, Blanch, Carreras, Rovira, Cirera, \& Gastó, 2005). The pattern of anxiety may reflect perceptions of uncertainty and threat at the beginning of the procedure, the increase in depression may reflect perceptions of a lengthening timeline, severe consequences, and ineffective coping, 
Acute stem cell transplantation: perceptions and coping predict distress

whilst stable stress may suggest a sustained level of challenge. However, anxiety peaked after transplantation in the present sample rather than closer to the transplant day as reported previously (Fife et al., 2000; Prieto, Atala, Blanch, Carreras, Rovira, Cirera, \& Gastó, 2005; Schulz-Kindermann et al., 2002; Tecchio et al., 2013). This could be due to the way in which the DASS-21 conceptualises anxiety. Unlike measures used in the other studies, the DASS-21, separates stress from anxiety and draws considerably on physical symptoms to measure the latter. Shortly following transplantation, physical symptoms may be exacerbated and patients await to find out whether engraftment has been successful, potentially contributing to the higher anxiety scores. Furthermore, some patients were admitted to hospital after transplantation (ambulatory care), which may also have contributed to a later rise in anxiety. Lower distress in younger individuals, men, and those with better physical functioning supports findings from previous studies (Prieto, Atala, Blanch, Carreras, Rovira, Cirera, \& Gastó, 2005; Schulz-Kindermann et al., 2002; Tecchio et al., 2013). Overall, our findings highlighted considerable complexity in patients' psychological needs.

\section{Limitations and strengths}

The findings need to be viewed in light of some limitations. The correlational evidence was unable to establish causation. HSCT perceptions and coping may also interact with physical functioning in predicting distress but such effects could not be examined. Social desirability may have resulted in more favourable reports, for example of coping style use. Results may not generalise to individuals with poorer physical functioning or higher stress, as missed time points were associated with both of these. Findings may also not generalise to other settings, minority groups, younger individuals, allogeneic patients, or patients with rarer diagnoses than the 
Acute stem cell transplantation: perceptions and coping predict distress

present sample. The novel Brief IPQ adaptation requires further validation whilst the Brief COPE is not exhaustive so that the observed effects regarding coping may not apply to other styles. Statistically, lack of convergence in some random effects models, limited internal consistency of some scales, and the small sample may have introduced bias. Reliability for some Brief COPE scales in particular was variable and at times limited. However, Cronbach's alpha is less suitable for small scales (such as the two-item Brief COPE scales) (Field, 2013) and such low coefficients are common in coping research even when larger groupings are used, including in HSCT (de Ridder, 1997; Folkman \& Moskowitz, 2004; Schoulte et al., 2011; Wells et al., 2009). As the Brief COPE is one of the most reliable scales in the field (de Ridder, 1997) and had shown good construct validity for the purpose of the study, the scale was considered acceptable for this initial investigation in spite of these limitations. Finally, the number of tests may have inflated Type I error, particularly for coping styles where overall analysis was not conducted. However, the findings are strengthened by a longitudinal design showing reliable and enduring effects, and a new and promising scale for HSCT perceptions. Consecutive referrals with reasons for nonparticipation, two sites, and the heterogeneity of the sample enhanced external validity. Finally, MLM with bootstrapping maximised the dataset, accounted for variability across participants, and improved statistical validity.

\section{Implications for nursing and conclusion}

The findings suggest the high rates of distress found during HSCT may be related to negative perceptions of the treatment. Further, active coping strategies that commonly alleviate distress during other medical procedures may not be as effective during HSCT. We suggest nurses concerned with the supportive care of patients leading up to and during HSCT can use these findings in three ways. First, 
Acute stem cell transplantation: perceptions and coping predict distress

negative perceptions of HSCT may be an indicator that a patient is at risk of developing distress during treatment, and require some psychological care. Second, such perceptions are potentially modifiable through discussion and information giving - research in other patient groups, including those with haematological malignancies more generally suggests this is possible (Husson et al., 2013; Broadbent, Ellis, Thomas, Gamble, \& Petrie, 2009; Keogh et al., 2011). Nurses may wish to use the framework of Leventhal's self-regulatory model, or indeed use the adapted IPQ used in this research, as a guide to help them explore negative perceptions of HSCT with patients. Third, nurses should advise patients that coping strategies aimed at avoiding or controlling aversive experiences of uncontrollable side effects may well be counter-productive. Psychological strategies such as acceptance and mindfulness might be more helpful responses to the challenges of HSCT. These methods have shown promise in the period during and following HSCT and could be feasibly integrated with standard clinical care (Bauer-Wu et al., 2008; Grossman et al., 2014).

Nurses should be aware that effectiveness research into pre-HSCT interventions aimed at preventing or reducing distress is in its infancy and no approach has substantively demonstrated its effectiveness (Baliousis et al., 2016). Future intervention research in this area may well benefit from targeting illness perceptions, acceptance, and mindfulness. In light of the range of complications associated with HSCT (Copelan, 2006), addressing negative perceptions and coping in such ways could play an important role in improving quality of life and physical outcomes. The benefits of such input could be diverse in domains such as improved pain and symptom tolerance, shorter hospital stay, better treatment adherence, faster immune recovery, and lower mortality (Hagger \& Orbell, 2003; Hoodin et al., 
Acute stem cell transplantation: perceptions and coping predict distress

2006; Prieto, Atala, Blanch, Carreras, Rovira, Cirera, Espinal, et al., 2005; Prieto et al., 2002; Pulgar et al., 2012; Schulz-Kindermann et al., 2002). However, replication of the present findings with larger samples and other clinical subgroups and settings remains necessary. Future studies into the role of physical functioning on perceptions, coping and broader coping categories, and distress, physical long-term outcomes, and establishing causality (e.g., via intervention) appear necessary.

\section{Conflict of interest}

The authors declare no conflict of interest.

\section{References}

Anderson, K., Giralt, S., Mendoza, T., Brown, J., Neumann, J., Mobley, G., . . . Cleeland, C. (2007). Symptom burden in patients undergoing autologous stem-cell transplantation. Bone Marrow Transplantation, 39(12), 759-766. doi:10.1038/sj.bmt.1705664

Antony, M. M., Bieling, P. J., Cox, B. J., Enns, M. W., \& Swinson, R. P. (1998).

Psychometric properties of the 42 -item and 21 -item versions of the Depression Anxiety Stress Scales (DASS) in clinical groups and a community sample. Psychological Assessment, 10(2), 176-181. doi:10.1037/10403590.10 .2 .176

Arran, N., Craufurd, D., \& Simpson, J. (2013). Illness perceptions, coping styles and psychological distress in adults with Huntington's disease. Psychology, Health \& Medicine, 19(2), 169-179. doi:10.1080/13548506.2013.802355

Baliousis, M., Rennoldson, M., \& Snowden, J. A. (2016). Psychological interventions for distress in adults undergoing haematopoietic stem cell transplantation: A systematic review with meta-analysis. Psycho-Oncology, 25(4), 400-411. doi: 10.1002/pon.3925 
Acute stem cell transplantation: perceptions and coping predict distress

Bauer-Wu, S., Sullivan, A. M., Rosenbaum, E., Ott, M. J., Powell, M., McLoughlin, M., \& Healey, M. W. (2008). Facing the challenges of hematopoietic stem cell transplantation with mindfulness meditation: a pilot study. Integrative Cancer Therapies, 7(2), 62-69. doi:10.1177/1534735408319068

Bautista, R. E. D., \& Erwin, P. A. (2013). Analyzing depression coping strategies of patients with epilepsy: A preliminary study. Seizure, 22(9), 686-691. doi:10.1016/j.seizure.2013.05.004

Bean, D., Cundy, T., \& Petrie, K. J. (2007). Ethnic differences in illness perceptions, self-efficacy and diabetes self-care. Psychology \& Health, 22(7), 787-811. doi:10.1080/14768320600976240

Braamse, A. M. J., Meijel, B., Visser, O. J., Boenink, A. D., Cuijpers, P., Eeltink, C. E., .. . Dekker, J. (2016). A randomized clinical trial on the effectiveness of an intervention to treat psychological distress and improve quality of life after autologous stem cell transplantation. Annals of Hematology, 95(1), 105-114. doi:10.1007/s00277-015-2509-6

Broadbent, E., Ellis, C. J., Thomas, J., Gamble, G., \& Petrie, K. J. (2009). Further development of an illness perception intervention for myocardial infarction patients: A randomized controlled trial. Journal of Psychosomatic Research, 67(1), 17-23. doi:10.1016/j.jpsychores.2008.12.001

Broadbent, E., Petrie, K. J., Main, J., \& Weinman, J. (2006). The Brief Illness Perception Questionnaire. Journal of Psychosomatic Research, 60(6), 631637. doi:10.1016/j.jpsychores.2005.10.020

Brown, T. A., Chorpita, B. F., Korotitsch, W., \& Barlow, D. H. (1997). Psychometric properties of the Depression Anxiety Stress Scales (DASS) in clinical samples. Behaviour Research and Therapy, 35(1), 79-89. 
Acute stem cell transplantation: perceptions and coping predict distress

Carver, C. S. (1997). You want to measure coping but your protocol's too long: Consider the brief cope. International Journal of Behavioral Medicine, 4(1), 92-100.

Carver, C. S., Pozo, C., Harris, S. D., Noriega, V., Scheier, M. F., Robinson, D. S., . . . Clark, K. C. (1993). How coping mediates the effect of optimism on distress: A study of women with early stage breast cancer. Journal of Personality and Social Psychology, 65(2), 375-390. doi:10.1037/0022-3514.65.2.375

Carver, C. S., Scheier, M. F., \& Weintraub, J. K. (1989). Assessing coping strategies: A theoretically based approach. Journal of Personality and Social Psychology, 56(2), 267-283. doi:10.1037/0022-3514.56.2.267

Cherrington, C. C., Moser, D. K., Lennie, T. A., \& Kennedy, C. W. (2004). Illness representation after acute myocardial infarction: Impact on in-hospital recovery. American Journal of Critical Care, 13(2), 136-145.

Cooper, C., Katona, C., Orrell, M., \& Livingston, G. (2008). Coping strategies, anxiety and depression in caregivers of people with Alzheimer's disease. International Journal of Geriatric Psychiatry, 23(9), 929-936. doi:10.1002/gps.2007

Copelan, E. A. (2006). Hematopoietic stem-cell transplantation. New England Journal of Medicine, 354(17), 1813-1826. doi:10.1056/NEJMra052638 de Ridder, D. (1997). What is wrong with coping assessment? A review of conceptual and methodological issues. Psychology \& Health, 12(3), 417-431. doi:10.1080/08870449708406717

Field, A. (2013). Discovering statistics using SPSS (4th ed.). London, England: Sage. 
Acute stem cell transplantation: perceptions and coping predict distress

Fife, B. L., Huster, G. A., Cornetta, K. G., Kennedy, V. N., Akard, L. P., \& Broun, E. R. (2000). Longitudinal study of adaptation to the stress of bone marrow transplantation. Journal of Clinical Oncology, 18(7), 1539-1549.

Figueiras, M. J., \& Alves, N. C. (2007). Lay perceptions of serious illnesses: An adapted version of the Revised Illness Perception Questionnaire (IPQ-R) for healthy people. Psychology \& Health, 22(2), 143-158.

doi:10.1080/14768320600774462

Folkman, S., \& Moskowitz, J. T. (2004). Coping: Pitfalls and promise. Annual Review of Psychology, 55, 745-774. doi:10.1146/annurev.psych.55.090902.141456

Grant, D. M., Wingate, L. R., Rasmussen, K. A., Davidson, C. L., Slish, M. L., Rhoades-Kerswill, S., . . . Judah, M. R. (2013). An examination of the reciprocal relationship between avoidance coping and symptoms of anxiety and depression. Journal of Social and Clinical Psychology, 32(8), 878-896. doi:10.1521/jscp.2013.32.8.878

Grossman, P., Zwahlen, D., Halter, J. P., Passweg, J. R., Steiner, C., \& Kiss, A. (2014). A mindfulness-based program for improving quality of life among hematopoietic stem cell transplantation survivors: feasibility and preliminary findings. Supportive Care in Cancer, 23(4), 1105-1112. doi:10.1007/s00520014-2452-4

Hagger, M. S., \& Orbell, S. (2003). A meta-analytic review of the common-sense model of illness representations. Psychology \& Health, 18(2), 141-184. doi:10.1080/088704403100081321

Hall, S., Weinman, J., \& Marteau, T. M. (2004). The motivating impact of informing women smokers of a link between smoking and cervical cancer: The role of 
Acute stem cell transplantation: perceptions and coping predict distress

coherence. Health Psychology, 23(4), 419-424. doi:10.1037/0278-

6133.23 .4 .419

Hefner, J., Kapp, M., Drebinger, K., Dannenmann, A., Einsele, H., Grigoleit, G. U., . . . Mielke, S. (2014). High prevalence of distress in patients after allogeneic hematopoietic SCT: Fear of progression is associated with a younger age. Bone Marrow Transplantation, 49(4), 581-584. doi:10.1038/bmt.2013.228

Helder, D. I., Kaptein, A. A., Kempen, G. M., Weinman, J., Houwelingen, H. C., \& Roos, R. A. (2002). Living with Huntington's disease: Illness perceptions, coping mechanisms, and patients' well - being. British Journal of Health Psychology, 7(4), 449-462. doi:10.1348/135910702320645417

Henry, J. D., \& Crawford, J. R. (2005). The short-form version of the Depression Anxiety Stress Scales (DASS-21): Construct validity and normative data in a large non-clinical sample. British Journal of Clinical Psychology, 44(2), 227239. doi:10.1348/014466505X29657

Hoodin, F., Uberti, J. P., Lynch, T. J., Steele, P., \& Ratanatharathorn, V. (2006). Do negative or positive emotions differentially impact mortality after adult stem cell transplant? Bone Marrow Transplantation, 38(4), 255-264.

Hooper, M. W., Baker, E. A., \& McNutt, M. D. (2013). Associations between coping, affect, and social support among low-income African American smokers. Addictive Behaviors, 38(11), 2736-2740. doi:10.1016/j.addbeh.2013.07.005

Husson, O., Thong, M. S. Y., Mols, F., Oerlemans, S., Kaptein, A. A., \& van de PollFranse, L. V. (2013). Illness perceptions in cancer survivors: what is the role of information provision? Psycho-Oncology, 22(3), 490-498. doi:10.1002/pon.3042 
Acute stem cell transplantation: perceptions and coping predict distress

IBM Corp. (2013). IBM SPSS Statistics for Windows (Version 22) [Computer software]. Armonk, NY: IBM Corp.

Keogh, K. M., Smith, S. M., White, P., McGilloway, S., Kelly, A., Gibney, J., \& O'Dowd, T. (2011). Psychological family intervention for poorly controlled type 2 diabetes. The American Journal of Managed Care, 17(2), 105-113.

Knibb, R. C., \& Horton, S. L. (2008). Can illness perceptions and coping predict psychological distress amongst allergy sufferers? British Journal of Health Psychology, 13(1), 103-119. doi:10.1348/135910706X173278

Knowles, S. R., Cook, S. I., \& Tribbick, D. (2013). Relationship between health status, illness perceptions, coping strategies and psychological morbidity: A preliminary study with IBD stoma patients. Journal of Crohn's and Colitis, 7(10), e471-e478. doi:10.1016/j.crohns.2013.02.022

Knowles, S. R., Nelson, E. A., Castle, D. J., Salzberg, M. R., Choong, P. F. M., \& Dowsey, M. M. (in press). Using the common sense model of illness to examine interrelationships between symptom severity and health outcomes in end-stage osteoarthritis patients. Rheumatology. doi:10.1093/rheumatology/kew022

Lazarus, R. S. (2000). Toward better research on stress and coping. American Psychologist, 55(6), 665-673. doi:10.1037/0003-066X.55.6.665

Lee, S. J., Loberiza, F. R., Antin, J. H., Kirkpatrick, T., Prokop, L., Alyea, E. P., . . . Soiffer, R. J. (2005). Routine screening for psychosocial distress following hematopoietic stem cell transplantation. Bone Marrow Transplantation, 35(1), 77-83. doi:10.1038/sj.bmt.1704709

Leventhal, H., Benyamini, Y., Brownlee, S., Diefenbach, M., Leventhal, E. A., Patrick-Miller, L., \& Robitaille, C. (1997). Illness representations: Theoretical 
Acute stem cell transplantation: perceptions and coping predict distress

foundations. In K. J. Petrie \& J. Weinman (Eds.), Perceptions of health and illness (pp. 19-46). Amsterdam, Netherlands: Harwood Academic Publishers.

Løchting, I., Garratt, A., Storheim, K., Werner, E., \& Grotle, M. (2013). Evaluation of the Brief Illness Perception Questionnaire in sub-acute and chronic low back pain patients: Data quality, reliability and validity. Journal of Pain \& Relief, 2(122), 1000122. doi:10.4172/2167-0846.1000122

Lovibond, S. H., \& Lovibond, P. F. (1995). Manual for the Depression Anxiety Stress Scales. Sydney, Australia: Psychology Foundation.

Meyer, B. (2001). Coping with severe mental illness: Relations of the Brief COPE with symptoms, functioning, and well-being. Journal of Psychopathology and Behavioral Assessment, 23(4), 265-277. doi:10.1023/A:1012731520781

Morgan, K., Villiers-Tuthill, A., Barker, M., \& McGee, H. (2014). The contribution of illness perception to psychological distress in heart failure patients. BMC Psychology, 2(1), 50. doi:10.1186/s40359-014-0050-3

Ng, F., Trauer, T., Dodd, S., Callaly, T., Campbell, S., \& Berk, M. (2007). The validity of the 21-item version of the Depression Anxiety Stress Scales as a routine clinical outcome measure. Acta Neuropsychiatrica, 19(5), 304-310. doi:10.1111/j.1601-5215.2007.00217.x

Ogden, J. (2012). Health psychology (5th ed.). Maidenhead, England: Open University Press.

Page, A. C., Hooke, G. R., \& Morrison, D. L. (2007). Psychometric properties of the Depression Anxiety Stress Scales (DASS) in depressed clinical samples. British Journal of Clinical Psychology, 46(3), 283-297. doi:10.1348/014466506X158996 
Acute stem cell transplantation: perceptions and coping predict distress

Park, J. E., Kim, K. I., Yoon, S. S., Hahm, B. J., Lee, S. M., Yoon, J. H., . . Oh, J. M. (2010). Psychological distress as a negative survival factor for patients with hematologic malignancies who underwent allogeneic hematopoietic stem cell transplantation. Pharmacotherapy: The Journal of Human Pharmacology and Drug Therapy, 30(12), 1239-1246. doi:10.1592/phco.30.12.1239

Parry, S. D., Corbett, S., James, P. J., Barton, R., \& Welfare, M. R. (2003). Illness perceptions in people with acute bacterial gastro-enteritis. Journal of Health Psychology, 8(6), 693-704. doi:10.1177/13591053030086004

Petrie, K. J., Broadbent, E., \& Meechan, G. (2003). Self-regulatory interventions for improving the management of chronic illness. In L. D. Cameron \& H. Leventhal (Eds.), The self-regulation of health and illness behaviour (pp. 257277). New York, NY: Routledge.

Petrie, K. J., Cameron, L. D., Ellis, C. J., Buick, D., \& Weinman, J. (2002). Changing illness perceptions after myocardial infarction: An early intervention randomized controlled trial. Psychosomatic Medicine, 64(4), 580-586.

Pillay, B., Lee, S. J., Katona, L., De Bono, S., Burney, S., \& Avery, S. (2015). A prospective study of the relationship between sense of coherence, depression, anxiety, and quality of life of haematopoietic stem cell transplant patients over time. Psycho-Oncology, 24(2), 220-227. doi:10.1002/pon.3633

Prieto, J. M., Atala, J., Blanch, J., Carreras, E., Rovira, M., Cirera, E., . . Gasto, C. (2005). Role of depression as a predictor of mortality among cancer patients after stem-cell transplantation. Journal of Clinical Oncology, 23(25), 60636071. doi:10.1200/JCO.2005.05.751

Prieto, J. M., Atala, J., Blanch, J., Carreras, E., Rovira, M., Cirera, E., \& Gastó, C. (2005). Patient-rated emotional and physical functioning among hematologic 
Acute stem cell transplantation: perceptions and coping predict distress

cancer patients during hospitalization for stem-cell transplantation. Bone Marrow Transplantation, 35(3), 307-314. doi:10.1038/sj.bmt.1704788

Prieto, J. M., Blanch, J., Atala, J., Carreras, E., Rovira, M., Cirera, E., \& Gastó, C. (2002). Psychiatric morbidity and impact on hospital length of stay among hematologic cancer patients receiving stem-cell transplantation. Journal of Clinical Oncology, 20(7), 1907-1917. doi:10.1200/JCO.2002.07.101

Pulgar, Á., Garrido, S., Alcalá, A., \& Reyes del Paso, G. A. (2012). Psychosocial predictors of immune response following bone marrow transplantation. Behavioral Medicine, 38(1), 12-18. doi:10.1080/08964289.2011.647118

Rasbash, J., Browne, W. J., Healy, M., Cameron, B., \& Charlton, C. (2015). MLwiN (Version 2.34) [Computer software]. Bristol, England: Centre for Multilevel Modelling, University of Bristol.

Rasbash, J., Steele, F., Browne, W. J., \& Goldstein, H. (2015). A User's Guide to MLwiN, v2.33. Bristol, England: Centre for Multilevel Modelling, University of Bristol.

Rizou, I., De Gucht, V., Papavasiliou, A., \& Maes, S. (2015). Illness perceptions determine psychological distress and quality of life in youngsters with epilepsy. Epilepsy \& Behavior, 46, 144-150. doi:10.1016/j.yebeh.2015.03.022

Ronk, F. R., Korman, J. R., Hooke, G. R., \& Page, A. C. (2013). Assessing clinical significance of treatment outcomes using the DASS-21. Psychological Assessment, 25(4), 1103-1110. doi:10.1037/a0033100

Schoulte, J. C., Lohnberg, J. A., Tallman, B., \& Altmaier, E. M. (2011). Influence of coping style on symptom interference among adult recipients of hematopoietic stem cell transplantation. Oncology Nursing Forum, 38(5), 582-586. doi:10.1188/11.ONF.582-586 
Acute stem cell transplantation: perceptions and coping predict distress

Schulz-Kindermann, F., Hennings, U., Ramm, G., Zander, A., \& Hasenbring, M. (2002). The role of biomedical and psychosocial factors for the prediction of pain and distress in patients undergoing high-dose therapy and BMT/PBSCT. Bone Marrow Transplantation, 29(4), 341-351. doi:10.1038/sj.bmt.1703385 Sharpe, L., \& Curran, L. (2006). Understanding the process of adjustment to illness. Social Science \& Medicine, 62(5), 1153-1166. doi:10.1016/j.socscimed.2005.07.010

Sikkema, K. J., Ranby, K. W., Meade, C. S., Hansen, N. B., Wilson, P. A., \& Kochman, A. (2013). Reductions in traumatic stress following a coping intervention were mediated by decreases in avoidant coping for people living with HIV/AIDS and childhood sexual abuse. Journal of Consulting and Clinical Psychology, 81(2), 274-283. doi:10.1037/a0030144

Snijders, T. A. B., \& Bosker, R. J. (2012). Multilevel analysis: An introduction to basic and advanced multilevel modeling (2nd ed.). London, England: Sage.

Tarrier, N. (2006). Case formulation in cognitive behaviour therapy: The treatment of challenging and complex cases. Hove, England: Routledge.

Taylor, S. E., \& Stanton, A. L. (2007). Coping resources, coping processes, and mental health. Annual Review of Clinical Psychology, 3, 377-401. doi:10.1146/annurev.clinpsy.3.022806.091520

Tecchio, C., Bonetto, C., Bertani, M., Cristofalo, D., Lasalvia, A., Nichele, I., .. . Ruggeri, M. (2013). Predictors of anxiety and depression in hematopoietic stem cell transplant patients during protective isolation. Psycho-Oncology, 22(8), 1790-1797. doi:10.1002/pon.3215

Twisk, J. W. R. (2006). Applied multilevel analysis: A practical guide. Cambridge, England: Cambridge University Press. 
Acute stem cell transplantation: perceptions and coping predict distress

Vaughan, R., Morrison, L., \& Miller, E. (2003). The illness representations of multiple sclerosis and their relations to outcome. British Journal of Health Psychology, 8(3), 287-301. doi:10.1348/135910703322370860

Wells, K. J., Booth-Jones, M., \& Jacobsen, P. B. (2009). Do coping and social support predict depression and anxiety in patients undergoing hematopoietic stem cell transplantation? Journal of Psychosocial Oncology, 27(3), 297-315. doi:10.1080/07347330902978947

Wu, L. M., Austin, J., Hamilton, J. G., Valdimarsdottir, H., Isola, L., Rowley, S., . . Rini, C. (2012). Self - efficacy beliefs mediate the relationship between subjective cognitive functioning and physical and mental well - being after hematopoietic stem cell transplant. Psycho-Oncology, 21(11), 1175-1184. doi:10.1002/pon.2012

Xuereb, M. C., \& Dunlop, R. (2003). The experience of leukaemia and bone marrow transplant: Searching for meaning and agency. Psycho-Oncology, 12(5), 397409. doi:10.1002/pon.648

Zoeckler, N., Kenn, K., Kuehl, K., Stenzel, N., \& Rief, W. (2014). Illness perceptions predict exercise capacity and psychological well-being after pulmonary rehabilitation in COPD patients. Journal of Psychosomatic Research, 76(2), 146-151. doi:10.1016/j.jpsychores.2013.11.021 
Acute stem cell transplantation: perceptions and coping predict distress

Table 1. Participant characteristics $(n=45)$

\begin{tabular}{ll}
\hline Characteristics & Overall $(\boldsymbol{n}, \%)$ \\
\hline Gender: male & $31(69 \%)$ \\
Marital status & \\
Married/cohabiting & $34(76 \%)$ \\
Single & $5(11 \%)$ \\
Other & $6(13 \%)$
\end{tabular}

Education

Mainstream only (Junior high school) $19(42 \%)$

Further (High school) $12(27 \%)$

Higher (College) $10(22 \%)$

Not known $4(9 \%)$

Diagnosis

Multiple myeloma $\quad 27(60 \%)$

$\mathrm{NHL} 12(27 \%)$

Other $\quad 6(13 \%)$

Transplant: Autologous 40 (89\%)

(Mean, SD)

Age on transplant day (years) $\quad 59.5(11.7)$

Years since diagnosis $\quad 2.40(3.47)$

Performance status (ECOG) $\quad 0.58(0.60)$

Length of admission (days) Ambulatory $(n=11,28 \%)$

$9.40(5.27)$

Nonambulatory ( $n=28,72 \%)$

$21.1(5.5)$

Note. $\mathrm{SD}=$ Standard deviation; NHL = Non-Hodgkin's lymphoma; ECOG = Eastern Cooperative Oncology Group scale; Ambulatory = Patients initially 
Acute stem cell transplantation: perceptions and coping predict distress attending day ward. Six transplants were cancelled and those patients could not be classified. 
Acute stem cell transplantation: perceptions and coping predict distress

Table 2. Mean distress over time (with percentage of patients reporting at least moderate levels) using multilevel modelling

\begin{tabular}{|c|c|c|c|c|c|c|c|c|c|}
\hline \multirow[t]{3}{*}{ Measure } & \multicolumn{4}{|c|}{$M(S D)$} & \multicolumn{5}{|c|}{ Effect of time } \\
\hline & \multirow[t]{2}{*}{ T1 } & \multirow[t]{2}{*}{ T2 } & \multirow[t]{2}{*}{ T3 } & \multirow[t]{2}{*}{ T4 } & \multirow[t]{2}{*}{$\Delta x^{2}$} & \multirow[t]{2}{*}{$R_{1}^{2}$} & \multicolumn{3}{|c|}{$\beta(S E)$} \\
\hline & & & & & & & & T3 & T4 \\
\hline Total distress (0-57) & $9.84(10.93)$ & $9.89(6.87)$ & $15.0(10.5)$ & $13.6(10.2)$ & $10.6^{*}$ & nil & $0.08(1.60)$ & $\begin{array}{l}3.74^{*} \\
(1.48)\end{array}$ & $2.74(1.47)$ \\
\hline Depression (0-21) & $\begin{array}{l}3.84(4.60) \\
(13 \%)\end{array}$ & $\begin{array}{l}2.47(2.64) \\
(9 \%)\end{array}$ & $\begin{array}{l}4.90(3.94) \\
(18 \%)\end{array}$ & $\begin{array}{l}5.39(5.13) \\
(24 \%)\end{array}$ & $31.1^{* \star \star}$ & $15 \%$ & $-0.83(0.57)$ & $\begin{array}{l}1.56^{\star *} \\
(0.56)\end{array}$ & $\begin{array}{l}2.17^{\star *} \\
(0.78)\end{array}$ \\
\hline Anxiety (0-15) & $\begin{array}{l}1.45(2.49) \\
(7 \%)\end{array}$ & $\begin{array}{l}1.38(1.78) \\
(11 \%)\end{array}$ & $\begin{array}{l}2.42(2.32) \\
(27 \%)\end{array}$ & $\begin{array}{l}1.00(1.24) \\
(4 \%)\end{array}$ & $\begin{array}{l}28.2^{\star \star \star} \\
(\Delta d f=4)\end{array}$ & $<0$ & $0.46(0.27)$ & $\begin{array}{l}1.53^{\star \star *} \\
(0.38)\end{array}$ & $0.16(0.32)$ \\
\hline Stress $(0-21)$ & $\begin{array}{l}4.55(4.94) \\
(11 \%)\end{array}$ & $\begin{array}{l}4.58(3.41) \\
(4 \%)\end{array}$ & $\begin{array}{l}4.64(5.09) \\
(9 \%)\end{array}$ & $\begin{array}{l}4.80(4.34) \\
(9 \%)\end{array}$ & $18.2^{\star *}$ & $<0$ & $-0.05(0.76)$ & $0.63(0.60)$ & $0.66(0.67)$ \\
\hline
\end{tabular}

Note. The range of each distress scale is shown next to each scale in parentheses; $M=$ Mean; $S D=$ Standard deviation; T1-4 = Time points 1 $4 ; \Delta X^{2}=-2 \log$ Likelihood change compared to baseline, $\Delta d f=3$ for fixed effects models and 5 for random effects models unless specified otherwise; $R_{1}{ }^{2}=$ Explained variance compared to intercepts-only model; $\beta=$ Fixed parameter estimate (compared to baseline); $S E=S t a n d a r d$ error; Shading $=$ Predictor set random at Level 2.

${ }^{* * *} P<0.001 ;{ }^{* *} P<0.01 ;{ }^{*} P<0.05$. 
Acute stem cell transplantation: perceptions and coping predict distress

Table 3. Summary of multilevel models for distress with negative HSCT perceptions and coping styles as predictors

\begin{tabular}{|c|c|c|c|c|c|c|c|c|c|c|c|c|}
\hline \multirow[t]{2}{*}{ Scale } & \multicolumn{3}{|c|}{ Total distress } & \multicolumn{3}{|c|}{ Depression } & \multicolumn{3}{|c|}{ Anxiety } & \multicolumn{3}{|c|}{ Stress } \\
\hline & $\Delta \mathrm{x}^{2}$ & $R_{1}^{2}$ & $\beta(S E)$ & $\Delta \mathrm{x}^{2}$ & $R_{1}^{2}$ & $\beta(S E)$ & $\Delta x^{2}$ & $R_{1}^{2}$ & $\beta(S E)$ & $\Delta x^{2}$ & $R_{1}^{2}$ & $\beta(S E)$ \\
\hline $\begin{array}{l}\text { Negative HSCT } \\
\text { perceptions }\end{array}$ & $60.5^{\star \star \star}$ & $34 \%$ & $\begin{array}{l}0.37^{\star \star \star} \\
(0.07)\end{array}$ & $53.8^{\star \star \star}$ & $28 \%$ & $\begin{array}{l}0.17^{\star \star \star} \\
(0.04)\end{array}$ & $42.2^{\star \star \star}$ & $38 \%$ & $\begin{array}{l}0.07^{\star \star \star} \\
(0.20)\end{array}$ & $36.9^{\star \star \star}$ & $28 \%$ & $\begin{array}{l}0.13^{* *} \\
(0.04)\end{array}$ \\
\hline Consequences & $24.8^{* * *}$ & $<0$ & $\begin{array}{l}0.85^{* * *} \\
(0.22)\end{array}$ & $18.8^{* * *}$ & $6 \%$ & $\begin{array}{l}0.45^{\star * *} \\
(0.11)\end{array}$ & $6.23^{*}$ & $3 \%$ & $\begin{array}{l}0.15^{\star} \\
(0.06)\end{array}$ & $47.5^{\star \star \star}$ & $<0$ & $\begin{array}{l}0.29 \text { ** } \\
(0.12)\end{array}$ \\
\hline Timeline & $40.1^{* \star \star}$ & $<0$ & $\begin{array}{l}1.18^{* *} \\
(0.41)\end{array}$ & $33.1^{* \star \star}$ & $<0$ & $\begin{array}{l}0.42^{*} \\
(0.19)\end{array}$ & $41.4^{\star \star *}$ & $<0$ & $\begin{array}{l}0.26^{*} \\
(0.11)\end{array}$ & $33.7^{\star \star \star}$ & $<0$ & $0.45^{\star}$ \\
\hline Identity & $42.0^{\star * \star}$ & $<0$ & $\begin{array}{l}0.75^{\star *} \\
(0.26)\end{array}$ & $25.3^{* * *}$ & $4 \%$ & $\begin{array}{l}0.49^{* * *} \\
(0.10)\end{array}$ & $23.9^{\star \star \star}$ & $<0$ & $\begin{array}{l}0.19^{* *} \\
(0.06)\end{array}$ & $28.6^{\star * \star}$ & $<0$ & $0.14(0.14)$ \\
\hline Concern & $16.4^{\star * \star}$ & $<0$ & $\begin{array}{l}1.30^{\star \star \star} \\
(0.28)\end{array}$ & 34.9 & $<0$ & $\begin{array}{l}0.50^{\star \star *} \\
(0.13)\end{array}$ & $31.1^{* * *}$ & $<0$ & $\begin{array}{l}0.21^{* *} \\
(0.07)\end{array}$ & $35.5^{\star \star \star}$ & $<0$ & $\begin{array}{l}0.56^{\star * *} \\
(0.15)\end{array}$ \\
\hline Understanding & $25.6^{* * *}$ & $<0$ & $\begin{array}{l}-1.15^{\star} \\
(0.50)\end{array}$ & $11.4^{* \star \star}$ & $7 \%$ & $\begin{array}{l}-0.53^{\star *} \\
(0.19)\end{array}$ & $32.1^{* * *}$ & $<0$ & $\begin{array}{l}-0.26^{*} \\
(0.12)\end{array}$ & 1.72 & $5 \%$ & $-0.37(0.20)$ \\
\hline Emotional impact & $71.7^{\star \star \star}$ & 0 & $\begin{array}{l}1.72^{* * *} \\
(0.24)\end{array}$ & $41.0^{* \star \star}$ & $35 \%$ & $\begin{array}{l}0.79^{\star * *} \\
(0.11)\end{array}$ & $42.9^{\star \star \star}$ & $<0$ & $\begin{array}{l}0.30^{\star * *} \\
(0.08)\end{array}$ & $38.0^{* \star *}$ & $37 \%$ & $0.79^{* \star *}$ \\
\hline
\end{tabular}


Acute stem cell transplantation: perceptions and coping predict distress

\begin{tabular}{|c|c|c|c|c|c|c|c|c|c|c|c|c|}
\hline Personal control & -0.35 & nil & $0.02(0.20)$ & 0.02 & nil & $-0.02(0.13)$ & $16.2^{* *}$ & $<0$ & $0.08(0.12)$ & 0.15 & nil & $0.05(0.13)$ \\
\hline Treatment control & 2.13 & nil & $0.11(0.36)$ & 0.32 & $1 \%$ & $-0.10(0.18)$ & 0.79 & nil & $0.08(0.09)$ & 0.54 & nil & $0.13(0.18)$ \\
\hline \multicolumn{13}{|l|}{ Coping } \\
\hline \multirow[t]{2}{*}{ Self-distraction } & 2.38 & $5 \%$ & $0.66(0.42)$ & 0.48 & $1 \%$ & $0.15(0.20)$ & 1.83 & $1 \%$ & $0.14(0.10)$ & $4.52^{*}$ & $10 \%$ & $0.45^{*}$ \\
\hline & & & & & & & & & & & & $(0.21)$ \\
\hline \multirow[t]{2}{*}{ Denial } & $28.0^{\star * *}$ & $35 \%$ & $3.53^{* *}$ & $23.3^{\star * *}$ & $28 \%$ & $1.98^{\star \star *}$ & $27.9^{* * *}$ & $33 \%$ & $0.46(0.28)$ & $6.58^{*}$ & $16 \%$ & $1.16^{* *}$ \\
\hline & & & (1.04) & & & $(0.36)$ & & & & & & $(0.42)$ \\
\hline \multirow{2}{*}{$\begin{array}{l}\text { Behavioural } \\
\text { disengagement }\end{array}$} & $29.6^{\star \star \star}$ & $33 \%$ & $4.28^{* *}$ & $35.0^{\star \star \star}$ & $34 \%$ & $2.64^{* * *}$ & $24.4^{\star * *}$ & $32 \%$ & $0.38(0.44)$ & $11.6^{\star * \star}$ & $10 \%$ & $1.51^{\star \star}$ \\
\hline & $(\Delta d f=2)$ & & (1.47) & $(\Delta d f=2)$ & & $(0.69)$ & & & & & & $(0.46)$ \\
\hline \multirow[t]{2}{*}{ Venting } & $28.8^{\star \star \star}$ & $28 \%$ & $2.54^{\star *}$ & $14.1^{* *}$ & nil & $0.70^{*}$ & $19.5^{\star \star \star}$ & $18 \%$ & $0.56^{* * *}$ & $28.0^{\star \star \star}$ & $33 \%$ & $1.32^{* \star *}$ \\
\hline & & & $(0.73)$ & & & $(0.33)$ & & & $(0.14)$ & $(\Delta d f=2)$ & & $(0.32)$ \\
\hline \multirow[t]{2}{*}{ Self-blame } & $44.0^{* * *}$ & $47 \%$ & $3.44^{* *}$ & $19.6^{* *}$ & $28 \%$ & $1.20^{*}$ & $47.1^{* * *}$ & $44 \%$ & $0.58^{*}$ & $28.4^{\star * *}$ & $34 \%$ & $1.51^{* \star *}$ \\
\hline & & & (1.05) & & & $(0.46)$ & & & $(0.25)$ & & & $(0.34)$ \\
\hline Active coping & 2.71 & $5 \%$ & $0.66(0.40)$ & 2.09 & $3 \%$ & $0.28(0.19)$ & 1.54 & $1 \%$ & $0.12(0.10)$ & 2.23 & $9 \%$ & $0.30(0.19)$ \\
\hline \multirow[t]{2}{*}{ Emotional support } & $9.69^{* *}$ & $6 \%$ & $1.02^{*}$ & 3.5 & $5 \%$ & $0.44^{*}$ & 3.15 & $2 \%$ & $0.16(0.11)$ & $6.01^{*}$ & $6 \%$ & $0.50^{*}$ \\
\hline & & & & & & $(0.21)$ & & & & & & $(0.20)$ \\
\hline
\end{tabular}


Acute stem cell transplantation: perceptions and coping predict distress

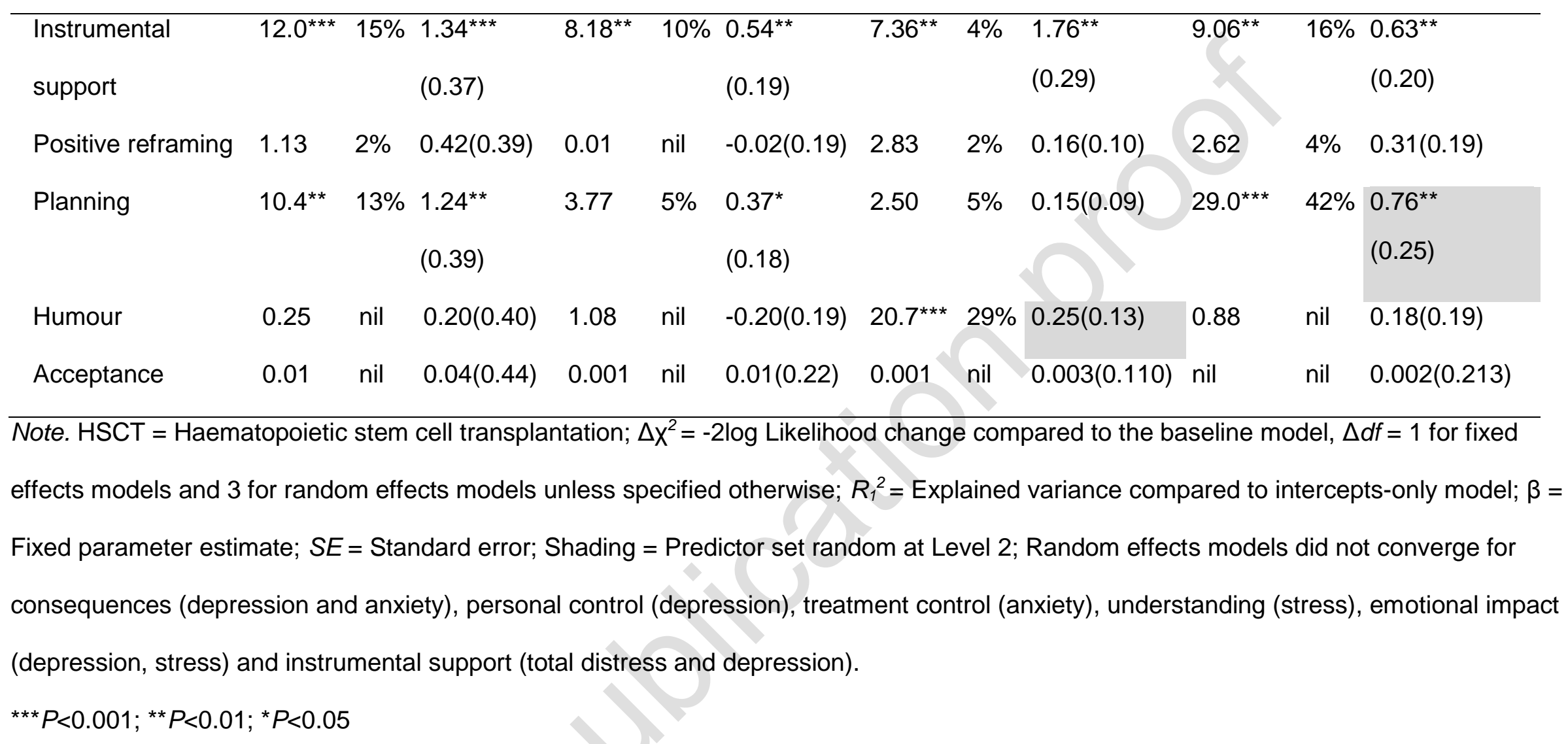


Acute stem cell transplantation: perceptions and coping predict distress

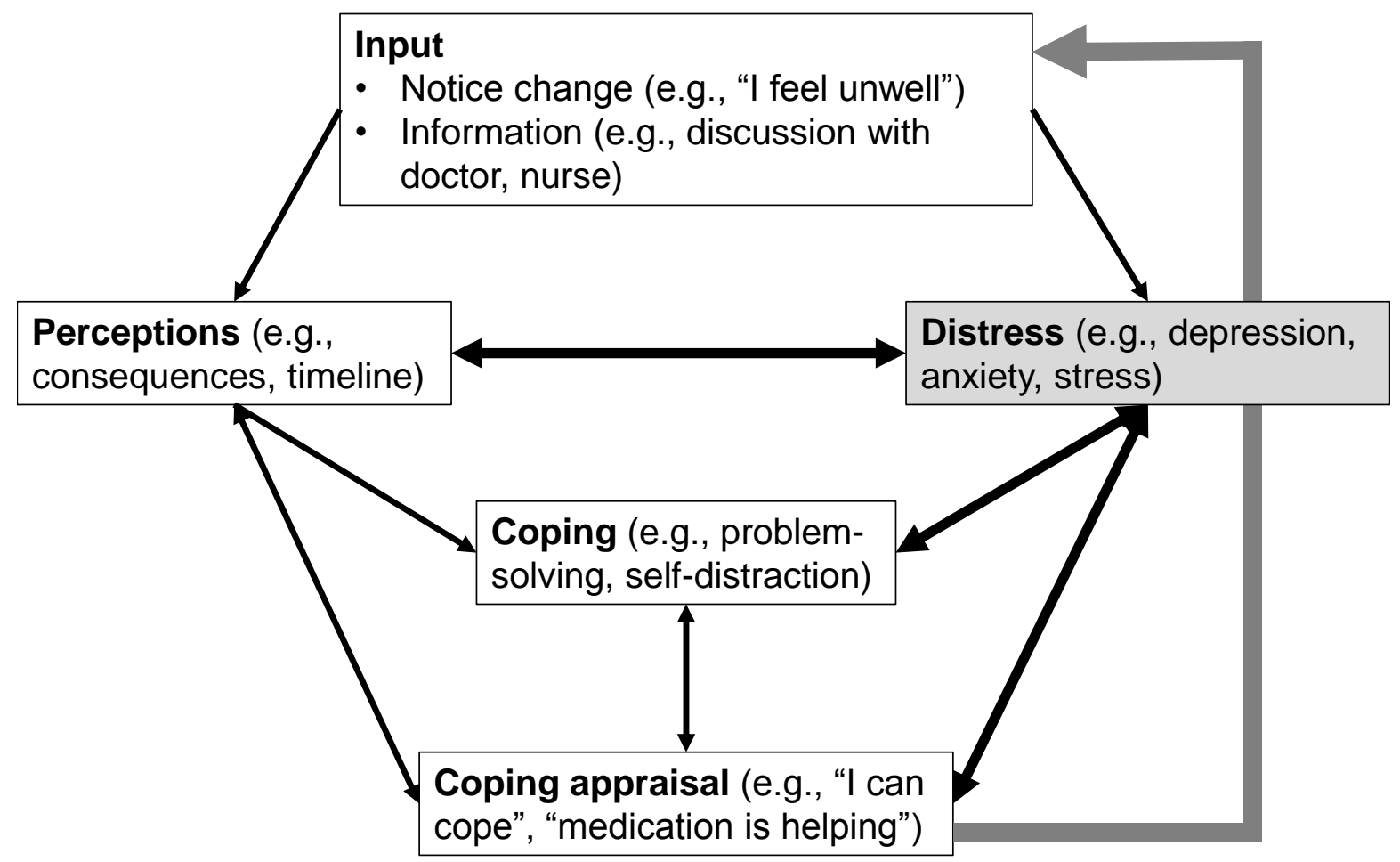

Figure 1. Relationships between perceptions, coping, coping appraisals, and distress and a feedback loop from coping appraisals to input, according to the selfregulatory model. The study examined the relationship between the model's psychological processes and distress (shown in bold). 
Acute stem cell transplantation: perceptions and coping predict distress

\begin{tabular}{|lc|}
\hline \multicolumn{2}{|c|}{ (Not eligible, $n=4)$} \\
Deaf & $(n=1)$ \\
Nonhaematological cancer & $(n=3)$ \\
\multicolumn{2}{|c|}{ (Declined, $n=54)$} \\
Unable to contact/consent prior to \\
transplant & $(n=18)$ \\
Procedure burden & $(n=18)$ \\
Unwell & $(n=7)$ \\
Taking part in other studies & $(n=3)$ \\
No benefit & $(n=4)$ \\
Distressed & $(n=1)$ \\
None given & $(n=3)$ \\
\hline
\end{tabular}

\section{Time points:}

1. Baseline

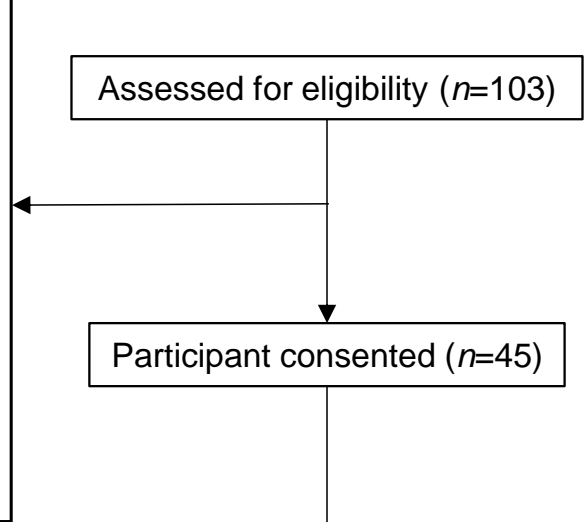

2. Day 0

3. Day $0+2$ weeks

4. Day $0+4$ weeks

\begin{tabular}{|c|c|}
\hline \multicolumn{2}{|c|}{ Assessment completed $(n=40)$} \\
\hline \multicolumn{2}{|l|}{ 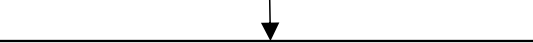 } \\
\hline \multirow{4}{*}{$\begin{array}{l}\text { Assessment completed } \\
\text { Delayed } \\
\text { Unavailable } \\
\text { Unwell }\end{array}$} & $(n=37)$ \\
\hline & $(n=2)$ \\
\hline & $(n=1)$ \\
\hline & $(n=1)$ \\
\hline Assessment not completed & $(n=8)$ \\
\hline \multirow{2}{*}{ Unwell } & $(n=2)$ \\
\hline & Transplant cancelled $\quad(n=6)$ \\
\hline \multicolumn{2}{|l|}{$\nabla$} \\
\hline \multirow{7}{*}{$\begin{array}{l}\text { Assessment completed } \\
\text { Delayed: unwell } \\
\text { Assessment not completed } \\
\text { Unwell } \\
\text { Transplant cancelled } \\
\text { No response } \\
\text { Withdrew }\end{array}$} & $(n=35)$ \\
\hline & $(n=6)$ \\
\hline & $(n=10)$ \\
\hline & $(n=2)$ \\
\hline & $(n=6)$ \\
\hline & $(n=1)$ \\
\hline & $(n=1)$ \\
\hline \multirow{10}{*}{\begin{tabular}{l} 
Assessment completed \\
Delayed \\
Unavailable \\
Unwell \\
Change in contact \\
\multicolumn{1}{c}{ details } \\
Assessment not completed \\
Transplant cancelled \\
Withdrew \\
No response \\
Deceased
\end{tabular}} & $(n=32)$ \\
\hline & $(n=8)$ \\
\hline & $(n=4)$ \\
\hline & $(n=3)$ \\
\hline & $(n=1)$ \\
\hline & $(n=13)$ \\
\hline & $(n=6)$ \\
\hline & $(n=3)$ \\
\hline & $(n=3)$ \\
\hline & $(n=1)$ \\
\hline 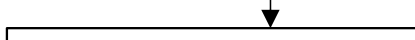 & \\
\hline Analysed & $(n=44)$ \\
\hline
\end{tabular}

Figure 2. Diagram of participant flow and completion of measurements. Responses were delayed if they exceeded two days from their due time. Participants who missed a time point could still complete later ones without having to be excluded 
Acute stem cell transplantation: perceptions and coping predict distress

altogether. Forty-four participants provided data for at least one time point for the analysis (144 data points in total). Day $0=$ Day of transplantation. 